FERREIRA, MAM; ANDRADE JUNIOR, VC; OLIVEIRA, AJM; FERREIRA, EA; BRITO, OG; SILVA, LR. 2019. Physiological characterization of plant growth in sweet potato. Horticultura Brasileira 37: 112-118. DOI - http://dx.doi.org/10.1590/S0102-053620190118

\title{
Physiological characterization of plant growth in sweet potato
}

\author{
Marcos Aurélio M Ferreira ${ }^{1} \mathbb{D}$; Valter C Andrade Junior ${ }^{2} \mathbb{D}$; Altino JM Oliveira ${ }^{2} \mathbb{D}$; Evander A Ferreira ${ }^{1} \mathbb{D}$; \\ Orlando G Brito ${ }^{1} \mathbb{D}$; Lidiane R Silva ${ }^{1} \mathbb{D}$
}

${ }^{1}$ Universidade Federal dos Vales do Jequitinhonha e Mucuri (UFVJM), Diamantina-MG, Brazil; marcosmamf23@yahoo.com.br; evanderalves@gmail.com; orlandocefet@yahoo.com.br; lirodrigues27@hotmail.com; ${ }^{2}$ Universidade Federal de Lavras (UFLA), LavrasMG, Brazil; valter.andrade@dag.ufla.br; altinojrmendes@gmail.com

\begin{abstract}
This research was installed to study plant growth of sweet potato and identify the most favorable harvest time for both roots and the aboveground part (stems). The experiment was carried out at the JK campus of the Federal University of the Vale do Jequitinhonha e Mucuri, in Diamantina, MG, complete blocks at random, with four replications. Three plants in the central part of the experimental plots were collected in twelve consecutive harvests at 15-day intervals. Plants were fractionated in roots, stems, and leaves to determine the dry matter of each part. Leaf area was also measured and growth rates were calculated. Data were analyzed by means of regression. Plants reached the highest dry matter accumulation between 75 and 156 days after transplanting (DAT), which corresponded to the phase of greatest growth. Plants should be harvested between 60 and 87 DAT to achieve the highest stem yield. For the highest root yield, the harvest should be carried out 180 DAT. The period from 80 to 118 DAT was the most adequate for reaching simultaneously the highest yields for both roots and stems. Therefore, the ideal harvest time for sweet potatoes depends on the use intended for the plant and on the physiological indexes associated with it.
\end{abstract}

Keywords: Ipomoea batatas, physiological indexes, human diet, animal feeding, harvest time.

\section{RESUMO}

Caracterização fisiológica do crescimento da planta de batata-doce

O objetivo deste trabalho foi caracterizar o crescimento da planta e determinar a melhor época de colheita da batata-doce, considerando raízes e parte aérea (ramas). $\mathrm{O}$ trabalho foi realizado no campus JK da Universidade Federal dos Vales do Jequitinhonha e Mucuri, em Diamantina-MG. O delineamento experimental foi blocos ao acaso, com quatro repetições. Foram realizadas doze coletas consecutivas de três plantas centrais da parcela, em intervalos de quinze dias. As plantas foram fracionadas em raiz, caule e folhas para a determinação das suas respectivas massas secas. A área foliar também foi mensurada e foram calculados os índices de crescimento. Os dados obtidos foram analisados por meio de regressão. Entre 75 e 156 dias após o transplantio (DAT), ocorreu o maior acúmulo de massa seca pela planta, caracterizando a fase de maior crescimento. Para maior rendimento de ramas, as plantas devem ser colhidas entre 60 e 87 DAT; para maior rendimento de raízes, a colheita deve ser realizada 180 DAT. O período de 80 a 118 DAT foi o mais adequado para a colheita simultânea de raízes e ramas, obtendo-se as maiores produtividades para ambos. Logo, a época ideal de colheita na batata-doce depende da sua finalidade de uso e de índices fisiológicos associados aos objetivos do cultivo.

Palavras-chaves: Ipomoea batatas, índices fisiológicos, alimentação humana, alimentação animal, época de colheita.

Received on January 4, 2018; accepted on October 10, 2018

$\mathrm{S}$ weet potato (Ipomoea batatas) is a traditional, widespread and very representative crop in Brazil, mainly for smallholder farmers (Azevedo et $a l ., 2014)$. The plant is used in several ways: roots are part of the human diet and are also employed in the industry for ethanol production, and stems are used for animal feeding (Gonçalves Neto et al., 2011; Andrade Júnior et $a l ., 2012)$. Yields are low in Brazil in general, despite the crop high potential
(Marchese et al., 2010). The Brazilian national average yield does not exceed $13.2 \mathrm{t} \mathrm{ha}^{-1}$, while Ethiopia (Africa) reaches average yields up to $45 \mathrm{t} \mathrm{ha}^{-1}$ (FAOSTAT, 2016).

Plant yield and growth are determined by various morpho-physiological characteristics, whose expression is governed by plant $x$ environment interactions. The quantitative analysis of growth allows a better understanding of the process by means of establishing growth indexes (Lopes et al., 2011) as result of the chronological quantification of dry matter accumulation and leaf area as a function of the plant growing cycle. Growth indexes also describe the plant morpho-physiological conditions and productive capacity (Barbero et al., 2013) and indicate the photosynthetic potential, partitioning of photosynthetic products throughout the different plant organs, and the contribution of these organs to the plant overall growth 
(Lopes et al., 2011; Strassburger et al., 2011). Finally, growth indexes allow for a more precise estimate of the best harvesting time (Nogueira et al., 1994).

Despite these advantages, studies on growth analysis of the sweet potato plant are scarce, especially in the view of the large variability of genetic materials grown in Brazil. One can cite, for example, the studies of Conceição et al. (2005), who estimated growth rates for two sweet potato cultivars, namely "da Costa" and "Abóbora", but without relating them to the harvest season.

Considering the above, the present study aimed to characterize the growth of sweet potato plants and to determine the best harvest time for the crop.

\section{MATERIAL AND METHODS}

The experiment was carried out in the field, from November 2015 to May 2016; in the Sector of Vegetables at the JK campus of the Federal University Vales do Jequitinhonha e Mucuri (UFVJM), in Diamantina, MG. The climate in the region is $\mathrm{Cwb}$ (oceanic, subtropical highland variety), Köppen classification (Sá Junior, 2009). Temperature, relative humidity, and the wind speed averaged $20.51{ }^{\circ} \mathrm{C}, 72.41 \%$, and $2.59 \mathrm{~m} \mathrm{~s}^{-1}$, respectively, during the experiment. The soil predominant in the experimental area is an Haplic Arenosol (FAO, 1994), with the following characteristics, according to the analysis made at the Soil Fertility Laboratory of UFVJM: $\mathrm{pH}=5.7 ; \mathrm{P}=119.0 \mathrm{mg} \mathrm{dm}^{-3} ; \mathrm{K}=337.5$ $\mathrm{mg} \mathrm{dm}{ }^{-3} ; \mathrm{Ca}=2.5 \mathrm{cmolc} \mathrm{dm}^{-3} ; \mathrm{Mg}=$ $0.7 \mathrm{cmolc} \mathrm{dm}^{-3} ; \mathrm{Al}=0.06 \mathrm{cmolc} \mathrm{dm}^{-3}$; $\mathrm{t}=4 \mathrm{cmolc} \mathrm{dm}^{-3} ; \mathrm{CEC}=5.9 \mathrm{cmolc} \mathrm{dm}^{-3}$; Aluminum saturation $=1.5 \%$; Base saturation $=67.7 \%$; Organic matter $=$ $0.8 \mathrm{dag} \mathrm{kg}^{-1} ; \mathrm{Cu}=0.01 \mathrm{mg} \mathrm{dm}^{-3} ; \mathrm{Fe}=$ $29.0 \mathrm{mg} \mathrm{dm}^{-3} ; \mathrm{Mn}=3.9 \mathrm{mg} \mathrm{dm}^{-3}$; and $\mathrm{Zn}=9.6 \mathrm{mg} \mathrm{dm}^{-3}$.

The area where the experiment was carried out has a history of use with vegetable crops, which allowed preparing the soil using minimum tillage, namely a single harrowing followed by manual hilling. According to soil analysis, $\mathrm{pH}$ did not any correction (Alvarez \& Ribeiro, 1999). The nitrogen fertilization consisted of
$60 \mathrm{~kg} \mathrm{ha}^{-1}$, split in two applications, the first at planting and, the second, 30 days later; and $10 \mathrm{t} \mathrm{ha}^{-1}$ of tanned bovine manure (Casali, 1999). We used the sweet potato clone Espanhola, from the UFVJM germplasm bank. The clone Espanhola was collected at and is widely distributed in the upper region of the river Jequitinhonha valley. Seedlings were produced out of $20-\mathrm{cm}$ long cuttings planted in 72-cell styrofoam trays, filled with commercial substrate, and kept in a greenhouse under $50 \%$ insolation, for 37 days.

Seedlings were transplanted in $1.20 \times 0.30 \mathrm{~m}$ spacing between rows and plants, respectively, in complete blocks at random, with four replications. Each block comprised 16 5-plant plots, three plants for analysis and two borders. Treatments consisted of twelve sampling times, starting fifteen days after transplanting and performed every two weeks. Plants were irrigated according to the average crop evapotranspiration, using conventional sprinkling irrigation. Spontaneous plants were controlled with hoes.

Plants were fractionated in roots, stems, and leaves, and weighed immediately after harvesting in a precision scale to obtain the fresh mass. Then, each fraction was placed in a paper bag and dried in a forced circulation oven, at $65^{\circ} \mathrm{C}$, until constant mass, for the determination of total root (RTDM), commercial root (CRDM), stem (MSC), leaf (MSF), aboveground (AGDM), and total plant dry matter (TDM), the later corresponding to roots + the aboveground part. Commercial roots were those weighing between 80 and 800 grams, free of damages or pest attack.

The leaf area (LA) was estimated from the sixth harvest, using the indirect method of the dry matter of leaf disks (Zeist et al., 2014). The dry matter of each part of the plant and the leaf area were used to define the growth parameters, using the formulas described by Peixoto et al. (2011) and Lopes et al. (2011):

1. Total dry matter accumulation (W $\left.=\mathrm{g} \mathrm{m}^{-2}\right)$ of roots $(\mathrm{WRTDM}=\mathrm{RTDM}$ $\left.\mathrm{S}^{-1}\right)$, commercial roots $(\mathrm{WCRDM}=$ CRDM S $\left.{ }^{-1}\right)$, stem $($ WSDM $=$ SDM
$\left.\mathrm{S}^{-1}\right)$, leaves $\left(\mathrm{WLDM}=\mathrm{LDM} \mathrm{S}^{-1}\right)$, aboveground part (WAGDM $=$ AGDM $\left.\mathrm{S}^{-1}\right)$, and plant $\left(\right.$ WTDM $=$ TDM S$^{-1}$, where $\mathrm{S}$ corresponds to the planting spacing;

2. Harvest indexes (HI, in \%) for roots $\left(\mathrm{HIRT}=\mathrm{RTDM} \mathrm{TDM}^{-1}\right)$, commercial roots $(\mathrm{HICR}=\mathrm{CRDM}$ $\mathrm{TDM}^{-1}$ ), and aboveground part (HIAG $=\mathrm{AGDM} \mathrm{TDM}^{-1}$ );

3. Plant absolute growth rate [(AGR $=\mathrm{g}$ day $\left.\left.^{-1}\right)=(\mathrm{P} 2-\mathrm{P} 1) /(\mathrm{T} 2-\mathrm{T} 1)\right]$;

4. Specific leaf area $\left[\left(\mathrm{SLA}=\mathrm{cm}^{2}\right.\right.$ $\left.\mathrm{g}^{-1}\right)=($ LA LDM], where LA refers to leaf area and, LDM, to leaf dry matter;

5. Relative growth rate for total roots (RGRTR), commercial roots (RGRCR), stems (RGRS), leaves (RGRL), the aboveground part (RGRAG), and plant (RGRP), using the formula [(RGR $=\mathrm{g} \mathrm{g}$ day $\left.^{1}\right)=(\ln (\mathrm{P} 2)-\ln (\mathrm{P} 1)) /(\mathrm{T} 2$ $-\mathrm{T} 1)]$, where $\ln (\mathrm{P} 2)$ and $\ln (\mathrm{P} 1)$ are the dry matter natural logarithms of the difference between two successive harvests in each fraction of the plant ; P2 and P1 are the dry matter of two successive harvests in each organ of the plant; and T2 and T1 are the harvest time (fixed in fifteen days in this study).

Data obtained for each plant fraction were submitted to analysis of variance, using the SISVAR statistics software (Ferreira, 2011) to calculate the $F$ value $(\mathrm{P}<0.05)$. Regression analysis was performed using the software SigmaPlot, v 10.0, whenever the harvesting effect was significant. We used the Simple Sigmoid models $\hat{y}=a /\left\{1+e^{-[(X-X 0) /}\right.$ $\left.{ }^{b}\right\}$, where $\hat{y}$ represents the analyzed variable, a refers to the asymptote corresponding to the maximum variable value, $\mathrm{X} 0$ corresponds to the curve medium point (inflection), and $b$, to the slope of the adjusted equation, and the Quadratic Polynomial model $\hat{y}=\mathrm{C}+\mathrm{Bx}$ $+\mathrm{Ax}^{2}$. The model was chosen according to the significance of the $\mathrm{F}$ test $(\mathrm{P}<0.05)$ for each regression equation and to the highest coefficient of determination $\left(\mathrm{R}^{2}\right)$.

\section{RESULTS AND DISCUSSION}

The dry matter accumulation, harvest index and the relative growth rate for 
each plant fraction had significant adjustments $(\mathrm{P}>0.05)$ to the simple sigmoid equation (Table 1), except for the relative growth rate for root total. Câmara et al. (2017) had already identified the same sigmoid dynamics for dry matter accumulation in sweet potato both with conventional and in vitro propagation. According to Peixoto et al. (2011), this is a classic growth

profile for plants: slow growth in the initial phase, followed by an exponential and later a more intense growth phase, and finally a new slow phase with a tendency to stabilization. Fitting to this pattern, sweet potato presented slow growth in the initial phase, from 15 to 60 days after transplanting (DAT) and then a phase of accelerated growth, up to 135 DAT, when the stabilization started

Table 1. Coefficients of the regression model for total dry matter accumulation of roots (WRTDM), commercial roots (WCRDM), stems (WCRS) and plant total (WTDM); harvest index for root total (HIRT), commercial roots (HIRC), leaves (HIL) and the aboveground part (HIAG) and; relative growth rate for stems (RGRS), leaves (RGRL), the aboveground part (RGRAG) and plant total (RGRP), depending on different sampling dates. Diamantina, UFVJM, 2017.

\begin{tabular}{lrrrrc}
\hline$\hat{\mathbf{Y}}$ & $\mathbf{a}$ & \multicolumn{1}{c}{$\mathbf{X 0}$} & $\mathbf{B}$ & $\mathbf{R}^{\mathbf{2}}$ & $\mathbf{F}(\mathbf{p}<\mathbf{0 , 0 5})$ \\
\hline WRTDM & $508.325^{*}$ & $109.826^{*}$ & $18.837^{*}$ & 0.96 & $139.85^{*}$ \\
WCRDM & $202.594^{\text {ns }}$ & $138.959^{*}$ & $24.168^{\text {ns }}$ & 0.75 & $13.54^{*}$ \\
WCRS & $54.490^{*}$ & $65.002^{*}$ & $8.846^{*}$ & 0.97 & $194.29^{*}$ \\
WTDM & $589.452^{*}$ & $92.940^{*}$ & $22.005^{*}$ & 0.97 & $182.74^{*}$ \\
HIRT & $105.040^{*}$ & $98.396^{*}$ & $48.626^{*}$ & 0.84 & $25.48^{*}$ \\
HIRC & $29.353^{*}$ & $117.619^{*}$ & $22.751^{\text {ns }}$ & 0.63 & $07.89^{*}$ \\
HIL & $54.518^{*}$ & $104.689^{*}$ & $-17.497^{*}$ & 0.80 & $19.16^{*}$ \\
HIAG & $78.956^{*}$ & $111.990^{*}$ & $-27.074^{*}$ & 0.88 & $36.02^{*}$ \\
RGRS & $0.052^{*}$ & $76.936^{*}$ & $-6.246^{\text {ns }}$ & 0.72 & $10.78^{*}$ \\
RGRL & $0.289^{\text {ns }}$ & $4.126^{\text {ns }}$ & $-24.709^{*}$ & 0.96 & $112.38^{*}$ \\
RGRAG & $0.095^{*}$ & $49.068^{*}$ & $-17.734^{*}$ & 0.96 & $108.46^{*}$ \\
RGRP & $0.102^{\text {ns }}$ & $46.020^{\text {ns }}$ & $-40.166^{*}$ & 0.87 & $28.94^{*}$ \\
\hline
\end{tabular}

$\hat{\mathrm{Y}}$ : analyzed variable; a: asymptote that corresponds to the maximum value of the variable; X0: curve midpoint (inflection); $\mathbf{b}$ : slope of the adjusted equation; $\mathbf{R}^{\mathbf{2}}$ : coefficient of determination; $\mathbf{F}$ : coefficient of the regression equation by the Fischer-Snedecor distribution. *The regression equation ( $\mathrm{F}$ test) and the coefficients of the regression equation ( $\mathrm{T}$ test) are significant $(\mathrm{P}<0.05)$; ${ }^{\text {ns }}$ ot significant.

Table 2. Coefficients of the regression model for dry matter accumulation in leaves (WLDM) and in the aboveground part (WAGDM); harvest index for stems (HIS); leaf area (LA); specific leaf area (SLA); and absolute plant growth rate (AGR) depending on different sampling dates. Diamantina, UFVJM, 2017.

\begin{tabular}{lrrrrc}
\hline$\hat{Y}$ & $\mathbf{C}$ & $\mathbf{B}$ & $\mathbf{A}$ & $\mathbf{R}^{2}$ & $\mathbf{F}(\mathbf{p}<\mathbf{0 , 0 5})$ \\
\hline WLDM & $-36.322^{\text {ns }}$ & $2.245^{*}$ & $-0.010^{*}$ & 0.75 & $14.03^{*}$ \\
WAGDM & $-59.048^{*}$ & $3.305^{*}$ & $-0.014^{*}$ & 0.81 & $20.28^{*}$ \\
HIS & $26.479^{*}$ & $-0.138^{\text {ns }}$ & $0.0002^{\text {ns }}$ & 0.74 & $12.86^{*}$ \\
LA & $1434.460^{*}$ & $-16.850^{*}$ & $0.054^{*}$ & 0.95 & $46.71^{*}$ \\
SLA & $25.271^{*}$ & $-0.286^{\text {ns }}$ & $0.0012^{\text {ns }}$ & 0.79 & $07.81^{*}$ \\
AGR & $-0.683^{\text {ns }}$ & $0.060^{*}$ & $-0.0003^{*}$ & 0.64 & $07.41^{*}$ \\
\hline
\end{tabular}

$\hat{Y}$ : analyzed variable; $\mathbf{C}$ : intersection between the curve and the Y-axis; B: Curve slope after the intersection; $\mathbf{A}$ : increasing or decreasing behavior of the curve; $\mathbf{R}^{\mathbf{2}}$ : coefficient of determination; and $\mathbf{F}$ : coefficient of the regression equation by the Fischer-Snedecor distribution. *The regression equation $(\mathrm{F}$ test) and the coefficients of the regression equation (T test) are significant $(\mathrm{P}<0.05)$; ${ }^{\text {ns }}$ not significant.
(Figure 1A).

Dry matter accumulation of leaf and the aboveground part, stem harvest index, leaf area, specific leaf area, and absolute growth rate had significant adjustment $(\mathrm{P}<0.05)$ to quadratic polynomial equations (Table 2 ). The quadratic adjustment for indexes and dry matter accumulation directly linked to leaves is pertinent. Conceição et al. (2004) evaluated two sweet potato cultivars and found that after the plants have reached the peak for dry matter accumulation there was a progressive decrease in the characteristic, once the rate of foliar senescence supplanted the rate of emission of new leaves.

The root system accumulated more dry matter than all other plant fractions, as shown by the adjusted equation for the accumulation of root total dry matter (WRTDM). The equation assumed the highest a value 180 DAT, equal to $508.32 \mathrm{~g} \mathrm{~m}^{-2}$ (Table 1), with a tendency to stabilize after 169 DAT (Figure 1A). The stabilization, followed by a decreasing trend in the accumulation of dry matter in roots is due to the sweet potato perennial cycle (Câmara et al., 2017), in which the plant redirects photosynthates and nutrients to resume the vegetative growth.

Commercial roots presented the second largest dry matter accumulation, with a value of $202.59 \mathrm{~g} \mathrm{~m}^{-2} 180$ DAT (Table 1). The aboveground part (stems + leaves) accumulated the maximum dry matter $\left(\mathrm{a}=135.89 \mathrm{~g} \mathrm{~m}^{-2}\right) 118$ DAT, ranking third in dry matter accumulation. When the aboveground part is fractioned in stem and leaves, leaves rank fourth in dry matter accumulation, $\mathrm{a}=89.67$ $\mathrm{g} \mathrm{m}^{-2} 113$ DAT, a value obtained by the derivative of the respective regression equation (Table 2). Stems were the plant fraction with the lowest dry matter accumulation, $\mathrm{a}=54.49 \mathrm{~g} \mathrm{~m}^{-2} 110$ DAT (Table 1), with a stabilization tendency observed already from 82 DAT (Figure 1A).

The adjusted curve for total dry matter accumulation in the plant (WPTDM) showed the aboveground part had the largest accumulation of photosynthates and nutrients at the beginning of the growth, between 15 and 75 DAT. From this point, roots became 
the site with the highest accumulation potential, as the dry matter accumulation in stems presented an early stabilization (Figure 1A), agreeing with the low b value (Table 1), and the dry matter accumulation in aboveground part as a whole also decreased. The development and growth of tuberous roots, which have a high capacity for photosynthate and nutrient mobilization, converted them into preferential metabolic drains, leading to the reduction in dry matter

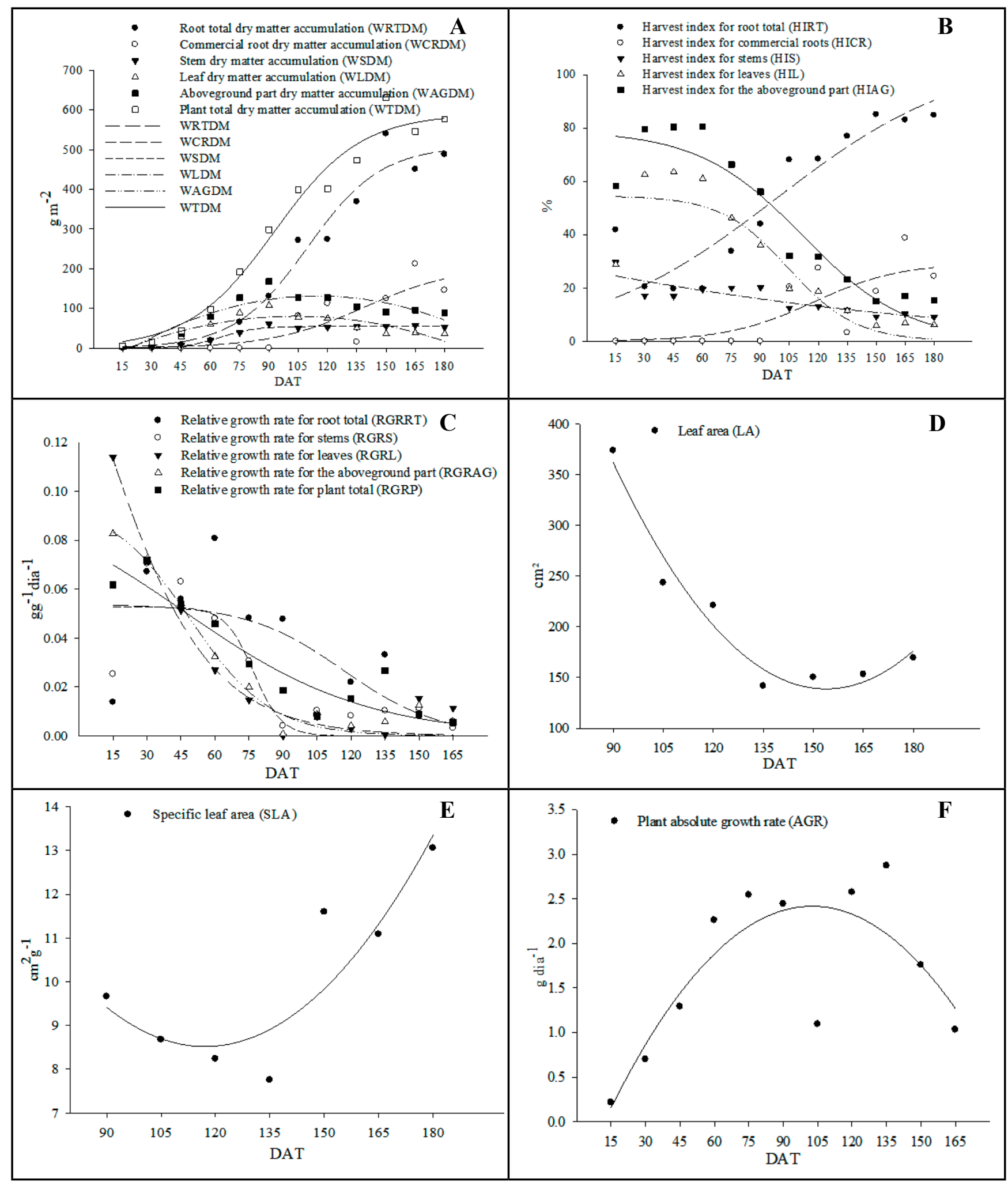

Figure 1. $A=$ Dry matter accumulation in different organs and total dry matter accumulation in the plant; $B=$ Harvest index in different plant organs; $\mathrm{C}=$ Relative growth rate in different organs and in the plant; $\mathrm{D}=$ Leaf area; $\mathrm{E}=$ Specific leaf area; and $\mathrm{F}=$ plant absolute growth rate DAT= days after transplanting seedlings to the field. Diamantina, UFVJM, 2017. 
accumulation in the aboveground part (Conceição et al., 2004).

The highest dry matter accumulation in the plant occurred 180 DAT, a $=589.45 \mathrm{~g} \mathrm{~m}^{-2}$, with a tendency to stabilize after 156 DAT (Figure 1A). On the contrary, the high $b$ values for dry matter accumulation of total plant, total roots, and commercial roots, respectively $22.00,18.83$, and 24.16 (Table 1), pointed to a weaker stabilization tendency. On the contrary, larger dry matter accumulation would, in fact, occur at the end of the evaluation period. The proximity among the $b$ values of these characteristics suggests that roots had the strongest influence over the sweet potato growth, which can be attributed to the greatest dry matter accumulation in this fraction. The increase in plant total dry matter has a direct relation with the tuberous roots, as roots represent a high proportion of the total dry matter (Conceição et al., 2004).

The harvest index (HI) refers to the plant ability to convert photosynthates into commercial products (Peixoto et al., 2011). In sweet potato, roots are the main commercial part for both food and industry. However, branches should also be considered to some extent, since their use for animal feeding has sparked interest as a nobler destination than simply discard (Andrade Júnior et al., 2012). The harvest index for root total (HIRT) had the highest a value, 105.04\%, 180 DAT (Table 1), a mathematical artifact because the maximum HIRT was close to $90 \%$ at this date (Figure 1B). Commercial roots reached maximum $\mathrm{HI}, \mathrm{a}=29.35 \%$, also 180 DAT, tending to stabilize after 156 DAT (Figure 1B). The high and positive $\mathrm{b}$ values in the HI equations for total (48.62) and commercial roots (22.75) indicate that both curves had a weak tendency to stabilize.

$\mathrm{HI}$ indicates that sweet potato plants should be harvested 180 DAT to obtain the highest yields for both total and commercial roots (Table 1). Azevedo et al. (2014) evaluated sweet potato root yield and quality in three cropping seasons at two locations and determined that the best harvesting date occurred 150 days after planting. Roesler et al. (2008) obtained the highest root yields in later harvests, 183 days after planting. These results agree with our findings with the HI for total and commercial roots.

The curve adjusted for the harvest index of the aboveground part (HIAG) had a decreasing behavior throughout the evaluation period, with high and negative $b$ value (-27.07) (Table 1), indicating a weak stabilization tendency. The maximum HIAG value, $\mathrm{a}=78.95 \%$, occurred 15 DAT, remained above $78 \%$ up to 60 DAT and was still above $70 \%$ 87 DAT (Figure 1B). Stems (HIS) and leaves (HIL) harvest indexes followed the same behavior as HIAG: the highest values appeared in the initial phase of development, higher than $20 \%$ for stems between 15 and 45 DAT, and over 50\% for leaves up to 85 DAT. Both indexes adjusted to equations with decreasing behavior (Figure 1B).

The behavior of HIAG, HIS and HIL suggests the plant lost its growth capacity, as well as the capacity to keep the aboveground part during its cycle, a process that can be attributed to the change in the pattern of dry matter distribution between roots $\mathrm{x}$ shoots + leaves with the progress of the vegetative cycle (Conceição et al., 2004). The HIAG adjusted equation indicated plants should be harvested up to 87 DAT to avoid further HI decreases (Table 1). Viana et al. (2011) did not find significant differences among the dry matter yield of stems of sweet potato clones harvested 120,150 and 180 days after planting. Even then, early harvests, as suggested here by the HIAG, would be preferable because later in the plant cycle, a numerical reduction in the aboveground part yield was noticed. If the objective is to promote the dualuse of the sweet potato plant, that is, to optimize both root and shoot production, the ideal harvest date is 101 DAT, when the intersection between HITR and HIAG took place, with HI of $56 \%$ (Figure 1B).

The relative growth rate (RGR) may be useful in estimating the partitioning of photoassimilates during growth (Barbero et al., 2013), as it represents the dry matter increment per dry matter unit in time ( $\mathrm{g} \mathrm{g}$ day $\left.^{-1}\right)$. The leaf(RGRL), stem (RGRS), aboveground part (RGRAG) and plant total (RGRP) relative growth rates reached the highest a values at the beginning of the cycle, respectively $0.28,0.05,0.09$, and $0.10 \mathrm{~g} \mathrm{day}^{-1}$ (Table 1). Leaves had the highest RGRL in initial evaluations, behaving both as source and as high potential metabolic drains, retaining a representative part of the photoassimilates (Conceição et al., 2005). The RGRS (stems) remained at $0.05 \mathrm{~g} \mathrm{~g} \mathrm{day}^{-1}$ up to $68 \mathrm{DAT}$ and then a sharp decline occurred (Figure 1C), which may have been caused by the mobilization of photosynthates to the roots, the reserve organ and, therefore, strong drain. The lowest $b$ value in relation to the other plant fractions in the adjusted RGRS equation (Table 1) indicates the curve had a greater tendency to stabilize than the equations adjusted to other organs. In other words, stems tend to present an earlier stagnation in growth.

The equations adjusted for each plant fraction and for the sweet potato plant as a whole showed a decreasing RGR during the analyzed period (Table 1). The plant ontogeny explains this growth profile. As plant organs develop and the plant approaches the physiological maturity, organ demands for photoassimilates for their own maintenance increases, reducing the photoassimilate availability for extra growth (Benincasa, 2003). Alvarez et al. (2012) found similar behavior when analyzing the relative growth and yield of rice cultivars in Botucatu, SP, and attributed the behavior to the advance in senescence, with leaf fall and death. Self-shading and the development of non-photosynthesizing organs can also reduce the RGR as the plant cycle advances, but it is very likely that mutual shading and leaf senescence are also involved (Silva et al., 2010).

Leaf area (LA) decreased between 90 and 154 DAT (Figure 1D), which may be associated with photoassimilates and nutrient distribution in the plant. Conceição et al. (2005) state the emergence of tuberous roots as strong metabolic drains and with great potential to mobilize assimilates accelerates leaf senescence and, consequently, reduces LA. LA has a fundamental role in determining the amount of light the 
plant intercepts, in carbon fixation, in water loss and even in ecosystem productivity (Nascimento et al., 2011). LA had increasing values after 154 DAT (Figure 1D), probably due to the resume in plant growth and the restructuring of its photosynthetic organ, the leaves. The sweet potato is a perennial plant, although cultivated as an annual crop (Silva et al., 2008).

The specific leaf area (SLA) is inversely related to leaf thickness, i.e., the higher the SLA, the thinner leaf blade and the larger leaf area are (Larcher, 2006). Therefore, SLA followed the same growth profile as LA, once SLA is directly proportional to LA and inversely proportional to leaf dry matter accumulation (WLDM) (Barreiro et al., 2006). As expected, SLA decreased between 90 and 119 DAT (Figure 1E), when LA was also decreasing and WLDM was approaching its peak (Figure 1A).The WLDM growth profile showed evidence of leaf blade thickening at the beginning of the evaluation period, which reverted after 119 DAT, when SLA started increasing, thus indicating a trend towards the development of new leaves and increase in the number of leaves. The leaves produced from 119 DAT had thinner blades and consequently larger leaf area than leaves produced at the beginning of the cycle. SLA reached the last evaluation (180 DAT) scoring slightly more than $13 \mathrm{~cm}^{2}$ per gram of leaf dry matter, strengthening the arguments that the plant tends to resume its photosynthetic activity and to restructure its photosynthetic apparatus. From this time, LA increased since sweet potato has a perennial cycle.

Plants had the highest absolute growth rate (AGR) 100 DAT, $2.31 \mathrm{~g}$ day $^{-1}$ (Figure 1F), with a decreasing movement after reaching the peak. AGR represents the plant average growth rate in a given period of time (Peixoto et al., 2011). In the present case, AGR indicates plants must be harvested from 100 DAT to meet both total root and stem production.

In summary, sweet potato plants had the most intense growing period between 75 and 156 DAT. Roots contributed the most to plant total growth because they accumulated more dry matter than all other plant fractions. The best harvest time depends on the plant use and the physiological indexes associated with it. To maximize total and commercial root yields, plants should be harvested 180 DAT. To maximize the aboveground part yield, stems should be harvested between 60 and 87 DAT. To meet both purposes, plants should be harvested between 80 and 118 DAT.

\section{ACKNOWLEDGMENTS}

To Fundação de Amparo a Pesquisa de Minas Gerais (FAPEMIG) and Conselho Nacional de Desenvolvimento Científico e Tecnológico (CNPq) for financial resources and scholarships to carry out the project. This study was financed in part by the Coordenação de Aperfeiçoamento de Pessoal de Nível Superior - Brasil (CAPES) - Finance Code 001.

\section{REFERENCES}

ALVAREZ, RCF; CRUSCIOL, CAC; NASCENTE,AS. 2012. Análise de crescimento e produtividade de cultivares de arroz de terras altas dos tipos tradicional, intermediário e moderno. Pesquisa Agropecuária Tropical 42: 397-406.

ALVAREZ, VVH; RIBEIRO, AC. 1999. Calagem. In: RIBEIRO, AC; GUIMARÃES, PTG; ALVAREZ VVH (eds). Recomendações para $o$ uso de corretivos e fertilizantes em Minas Gerais - $5^{a}$ Aproximação. Viçosa: CFSEMG. p. $43-60$

ANDRADE JÚNIOR, VC; VIANA, DJS; PINTO, NAVD; RIBEIRO, KG; PEREIRA, RC; NEIVA, IP; AZEVEDO, AM; ANDRADE, PCR. 2012. Características produtivas e qualitativas de ramas e raízes de batata-doce. Horticultura Brasileira 30: 584-589.

AZEVEDO, AM.; ANDRADE JÚNIOR, VC; VIANA, DJS; ELSAYED, AYAM PEDROSA, CE; NEIVA, IP; FIGUEIREDO, JA. 2014. Influência da época de colheita e locais de cultivo na produtividade e qualidade da batata-doce. Horticultura Brasileira 32 21- 27.

BARBERO, LM; PRADO, TF; BASSO, KC; LIMA, LA; MOTTA, KM; KRÜGER, BC; MARTINS NETO, LR; SILVA, GAS. 2013 Análise de crescimento em plantas forrageiras aplicada ao manejo de pastagens. Veterinária Notícias 19: 71- 85 .

BARREIRO, AP; ZUCARELI, V; ONO, EO; RODRIGUES, JD. 2006. Análise de crescimento de plantas de manjericão tratadas com reguladores vegetais. Bragantia 65: 563-567.

BENINCASA, MMP. 2003. Análise de crescimento de plantas: noções básicas. 2. ed. Jaboticabal: Funep. 41p.

BRAGA CL; FERNANDES, DM; SIRTOLI, LF; LUDWIG, F. 2010. Análise de crescimento de girassol ornamental de vaso e aplicação de nitrogênio. Scientia Agraria Paranaensis 9: 52-59.

CÂMARA, FAA; GRANGEIRO, LC; DOMBROSKI, JLD; FREITAS, RMO; FREITAS, FCL; NEGREIROS, MZ. 2017. Crescimento de cultivares de Ipomoea batatas oriundas de rebentos produzidas de forma convencional e in vitro. Revista de Ciências Agrárias 402: 53-60.

CASALI, VWD. 1999. Batata-doce. In: RIBEIRO, AC; GUIMARÃES, PTG; ALVAREZ, VVH (eds). Recomendações para o uso de corretivos e fertilizantes em Minas Gerais - $5^{a}$ Aproximação. Viçosa: CFSEMG, p. 180.

CONCEIÇÃO, MK; LOPES, NF; FORTES, GRL. 2004. Partição de matéria seca entre órgãos de batata-doce (ipomoea batatas (1.) lam), cultivares Abóbora e Da Costa. Revista Brasileira Agrociência 10: 313-316.

CONCEIÇÃO, MK; LOPES, NF; FORTES, GRL. 2005. Análise de crescimento de plantas de batata-doce (Ipomoea batatas (1.) Lam) cultivares Abóbora e da Costa. Revista Brasileira Agrociência 11: 273-278.

FAO (Food and Agriculture Organization). 1994. World reference base for soil resources: draft. Paris: UNESCO. 161p.

FAOSTAT - Food and Agriculture Organization of the United Nations Statistics Division. Sweet potatoes. Available at $<\mathrm{http} / / /$ faostat3.fao. org/browse/Q/QC/E $>$. Accessed December 9, 2016.

FERREIRA, DF. 2011. Sisvar: um sistema de análise estatística computador. Ciência e Agrotecnologia 35: 1039-1042.

GONÇALVES NETO, AC; MALUF, WR; GOMES, LAA; GONÇALVES, RJS; SILVA, VF; LASMAR, A. 2011. Aptidões de genótipos de batatadoce para consumo humano, produção de etanol e alimentação animal. Pesquisa Agropecuária Brasileira 46: $1513-1520$

LARCHER, W. 2006. Ecofisiologia Vegetal. São Carlos: Rima. p. 256

LOPES, WAR; NEGREIROS, MZ; DOMBROSKI, JLD; RODRIGUES, GSO; SOARES, AM; ARAÚJO, AP. 2011. Análise do crescimento de tomate 'SM-16' cultivado sob diferentes coberturas de solo. Horticultura Brasileira 29: 554-561.

MARCHESE, A; MALUF, WR, GONÇALVES NETO, AC; GONÇALVES, RJS; GOMES, LAA. 2010. Seleção de clones de batatadoce resistentes a Meloidogyne incognita raça 1. Pesquisa Agropecuária Brasileira 45: $997-$ 1004.

NASCIMENTO, HHC; NOGUEIRA, RJMC; SILVA, EC; SILVA, MS. 2011. Análise do crescimento de mudas de jatobá (Hymenaea courbaril L.) em diferentes níveis de água no solo. Revista Árvore 35: 617-626.

NOGUEIRA, SSS; NAGAI, V; BRAGA, NR; 
NOVO, MCSS; CAMARGO, MBP. 1994. Growth analysis of chickpea (Cicer arietinum L.).Scientia Agrícola 51: 430-435.

PEIXOTO, CP; CRUZ, TV; PEIXOTO, MFSP. 2011. Análise quantitativa do crescimento de plantas: conceitos e prática. Enciclopédia Biosfera: Centro Cientifico Conhecer 7: 51-76.

ROESLER, PVSO; GOMES, SD; MORO, E; KUMMER, ACB; CEREDA, MP 2008. Produção e qualidade de raiz tuberosa de cultivares de batata-doce no oeste do Paraná. Acta Scientiarum Agronomy 30: 117-122.

SÁ JÚNIOR, A. 2009. Aplicação da classificação de Koppen para o zoneamento climático do estado de Minas Gerais. Lavras: UFLA. 101p. (M.Sc. thesis).
SILVA, JBC; LOPES, CA; MAGALHÃES, JS. 2008. Batata-doce (Ipomoea batatas). Embrapa: Sistema de produção 6. Versão eletrônica. Available at http:// sistemasdeproducao.cnptia.embrapa.br/ FontesHTML/Batata-doce/Batata-doce Ipomoea_batatas/autores.htm. Accessed November 3, 2016

SILVA, PIB; NEGREIROS, MZ; MOURA, KKCF; FREITAS, FCP; NUNES, GHS; SILVA, PSL; GRANGEIRO, LC. 2010. Crescimento de pimentão em diferentes arranjos espaciais. Pesquisa Agropecuária Brasileira 45:132-139.

STRASSBURGER, AS; PEIL, RMN; FONSECA, LA; AUMONDE, TZ; MAUCH, CR. 2011.
Dinâmica de crescimento da abobrinha italiana em duas estações de cultivo. Acta Scientiarum Agronomy 33: 283-289.

VIANA, DJS; ANDRADE JÚNIOR, VCA; RIBEIRO, KG; PINTO, NAVD; NEIVA, IP; FIGUEIREDO, JA; LEMOS, VT; PEDROSA, CE; AZEVEDO, AM. 2011. Potencial de silagens de ramas de batata-doce para alimentação animal. Ciência Rural 41: 1466-1471.

ZEIST, AR; OLIVEIRA, JRF; LIMA FILHO, RB; SILVA, MLS; RESENDE, JTV. 2014. Comparação de métodos de estimativa de área foliar em morangueiro. Pesquisa Agropecuária Gaúcha 20: 33-41. 